Navigation Physics 2(1) (2020)
Navigation Physics
Journal of Physics Education

\title{
UJI GETARAN SEISMIK PADA RANCANG BANGUN REAL TIME SEISMIC MEASUREMENT (RSAM) MENGGUNAKAN FAST FOURIER TRANSFORM (FFT)
}

\author{
Umi Salamah ${ }^{1}$, Apik Rusdiarna Indra Praja ${ }^{2}$ \\ ${ }^{1,2}$ Program Studi Fisika, Fakultas Matematika dan Ilmu Pengetahuan Alam Universitas Ahmad Dahlan \\ Yogyakarta, Jln. Ring Road Selatan Tamanan Banguntapan Bantul Yogyakarta \\ Email: umi.salamah@fisika.uad.ac.id
}

\begin{tabular}{|c|c|}
\hline Info Artikel & Abstract \\
\hline $\begin{array}{l}\text { Sejarah Artikel: } \\
\text { Diterima April } 2020 \\
\text { Disetujui Mei } 2020 \\
\text { Dipublikasikan Juni } 2020 \\
\\
\text { Keywords: } \\
\text { Seismic Vibration } \\
\text { Seismic measurement } \\
\text { Fast Fourier Transform (FFT) }\end{array}$ & $\begin{array}{l}\text { Indonesia is one of the countries with the most volcanoes in the world. } \\
\text { Observation, monitoring, recording, dissemination of information and } \\
\text { warning of danger signs for volcanic activity is one of the focuses in the } \\
\text { response to volcanic disasters. The instrument used to monitor volcanic } \\
\text { activity is Real-time Siesmic Amplitude Measurement (RSAM). RSAM is } \\
\text { a system that provides a continuous measurement of the seismic amplitude } \\
\text { of the absolute average of the number of seismic stations. RSAM occupies } \\
\text { a strategic role in monitoring volcanic seismic activity, especially in times } \\
\text { of crisis before the eruption. In this study designing RSAM systems using } \\
\text { geophone sensors to detect seismic vibrations. System testing is done by } \\
\text { varying the test frequency. The test frequency given starts from } 10 \mathrm{~Hz} \text { to } 50 \\
\text { Hz. The results of this study indicate that a system that has been designed } \\
\text { to build can detect vibration signals well. This is evidenced by the Fast } \\
\text { Fourier Transform (FFT) spectrum which shows the suitability of the test } \\
\text { frequency with the spectrum peak produced. }\end{array}$ \\
\hline
\end{tabular}

How to Cite: Salamah, U., \& Praja, A. R.I. (2020). Uji getaran seismik pada rancang bangun Real Time Seismic Measurement (RSAM) menggunakan Fast Fourier Transform (FFT). Navigation Physics, 2 (1): 21-24.

\section{PENDAHULUAN}

Indonesia mempunyai rangkaian gunungapi membentang dari Pulau Sumatera, Jawa, Bali dan Nusa Tenggara. Dari kepulauan di Laut Bdana sampai bagian utara Pulau Sulawesi merupakan daerah gunungapi terpanjang di dunia. Indonesia memiliki 129 gunungapi aktif, 70 buah diantaranya berancaman dan 500 buah tidak aktif. Sejak tahun 1800, paling tidak telah tercatat 600 kali letusan oleh 70 gunungapi di Indonesia. Indonesia merupakan salah satu negara dengan gunungapi terbanyak di dunia. Rangkaian gunungapi membentang dari Pulau Sumatera, Jawa, Bali dan Nusa Tenggara. Dari kepulauan di Laut Bdana sampai bagian utara Pulau Sulawesi merupakan daerah gunungapi terpanjang di dunia. Indonesia memiliki 129 gunungapi aktif, 70 buah diantaranya berancaman dan 500 buah tidak aktif. Sejak tahun 1800 , paling tidak telah tercatat 600 kali letusan oleh 70 gunungapi di Indonesia. Oleh sebab itu, Indonesia dapat dikatakan sebagai negara yang rawan bencana khususnya ancaman bencana gunungapi. Secara umum aktivitas vulkanik Gunungapi dimulai dengan ekstruksi magma pada kubah yang disertai dengan runtuhnya sebagian kubah sehingga menyebabkan longsoran batuan dan guguran piroklastik, hingga akhirnya mengalami erupsi besar (Walter dkk, 2007). Pengamatan, pemantauan, pencatatan, penyebaran informasi dan peringatan tanda bahaya gunungapi menjadi salah satu fokus dalam penanggulangan bencana gunungapi. Salah satu instrumentasi yang digunakan untuk memonitoring aktivitas vulkanik Gunungapi adalah Real-time Siesmic Amplitude Measurement (RSAM). RSAM merupakan sistem yang menyediakan pengukuran berkelanjutan mengenai amplitude seismik ratarata absolut dari jumlah stasiun seismik (Ratdomopurbo dan Sampurno, 2000, Santoso dkk, 2013).

RSAM menempati peranan strategis dalam monitoring aktivitas seismik gunungapi terutama pada saat krisis menjelang erupsi. Sistem RSAM yang ada saat ini masih dapat dikembangkan lebih lanjut lagi (Suharno dkk, 2010). Dalam penelitian sebelumnya telah dirancang bangun RSAM dengan memanfaatkan sistem mikrokontroler yang sedang berkembang dan populer saat ini yaitu menggunakan 
Arduino (Salamah dkk, 2019). Salah satu indikator untuk mengetahui kehandalan dari sistem RSAM adalah dengan mengetahui respon getaran yang diterima. Semakin akurat respon getaran tersebut semakin handal sistem tersebut. Oleh sebab itu, dalam penelitian ini dilakukan uji respon geratan sistem RSAM yang telah dirancang bangun dengan menggunakan FFT.

\section{METODE PENELITIAN}

Perancangan RSAM diawali dengan cara memilih komponen rancangan elektronika, komunikasi digital dan pengolahan sinyal digital. Modul RSAM yang sudah terancang bangun dihubungkan dengan sensor geophone dan ujikan dalam skala laboratorium sebelum diujikan dalam skala lapangan. Blok diagram sistem RSAM terkomputerisasi ditampilkan pada Gambar 1.

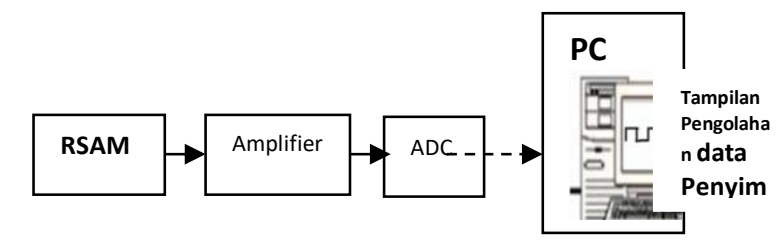

Gambar 1.Blok diagram sistem RSAM terkomputerisasi (Salamah dkk, 2019)

Sinyal seismik yang dideteksi ditampilkan dalam interface. Desain interface dalam penelitian ini menggunkan Delphi sebagai software pendukungnya. Tampilan desain interface ditunjukan pada Gambar 2 di bawah ini.

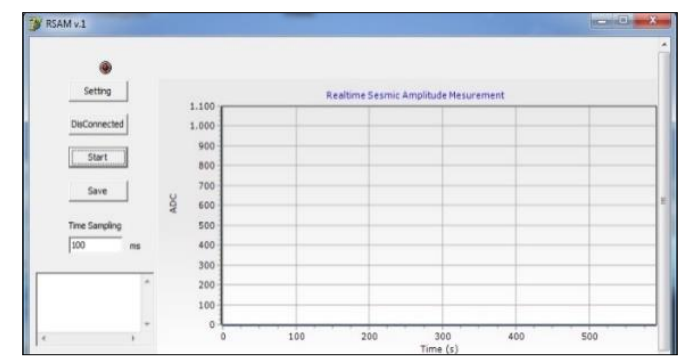

Gambar 2. Interface sistem RSAM (Salamah dkk, 2019)

Analisis data pada penelitian ini menggunakan FFT. FFT merupakan satu bentuk transformasi yang umum digunakan untuk merubah sinyal dari domain waktu ke domain frekuensi adalah dengan transformasi Fourier. Formulasi umum dari FFT dituliskan pada Persamaan 1 di bawah ini.

$$
X(\omega)=\int_{-x}^{x} x(t) e^{-j \omega t} d t
$$

Persamaan ini merupakan bentuk transformasi Fourier yang siap dikomputasi secara langsung dari bentuk sinyal $\mathrm{x}(\mathrm{t})$ (Santosa dan Huda, 2009). Software pendukung dalam penelitian ini adalah menggunakan Matlab yang mana sudah tersedia library FFT di dalamnya. Secara umum, untuk menganalisis sebuah sinyal dengan FFT dilakukan dengan dua langkah yaitu langkah pertama dengan membangkitkan sinyal sinus yang memilki frekuensi dan amplitude tertentu. Langkah kedua memanggil library FFT untuk mentranformasi sinyal ke dalam domain frekuensi.

\section{HASIL DAN PEMBAHASAN}

Sistem RSAM yang telah dirancang bangun mempunyai beberapa komponen antara sensor geophone, arduino dan rangkaian RSAM. Pada Gambar 3 di bawah ini menampilkan fotograf modul elektronik dari sistem RSAM tersebut. 


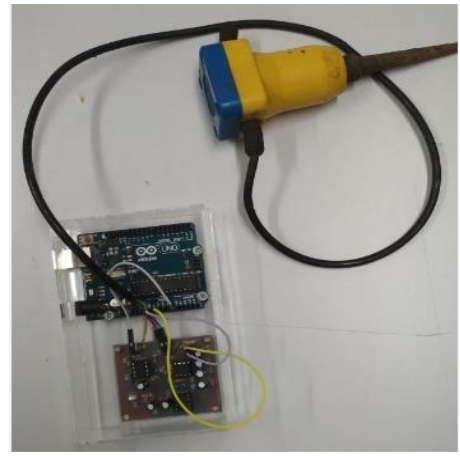

Gambar 3. Modul elektronik sistem RSAM (Salamah dkk, 2019)

Uji getaran seismic dilakukan dengan menggunakan Audio Frekuensi Generator (AFG). Variasi frekuensi uji yang diberikan pada pengujian ini adalah $10 \mathrm{~Hz}, 20 \mathrm{~Hz}, 30 \mathrm{~Hz}, 40 \mathrm{~Hz}$ dan $50 \mathrm{~Hz}$. Pada pengujian tersebuat diperoleh sinyal seismik dalam domain waktu yang selanjutnya dilakukan analisa sinyal menggunakan Fast Fourier Transform (FFT). Dengan melakukan FFT pada sinyal seismik, maka akan diperoleh spektrum FFT atau spektrum frekuensi dari sinyal tersebut. Sampel respon sistem terhadap frekuensi uji dan spektrum frekuensi hasil FFT ditunjukan pada Gambar 4 di bawah ini.

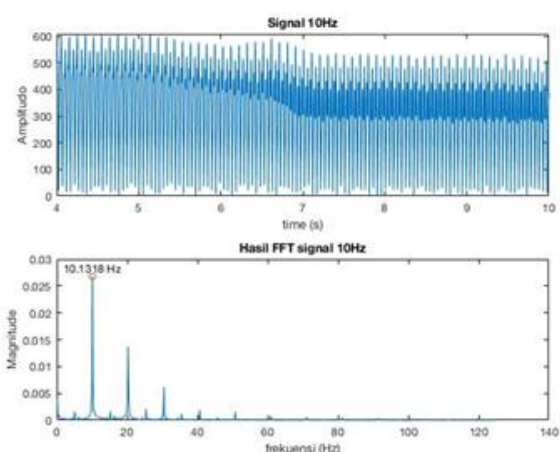

(a)

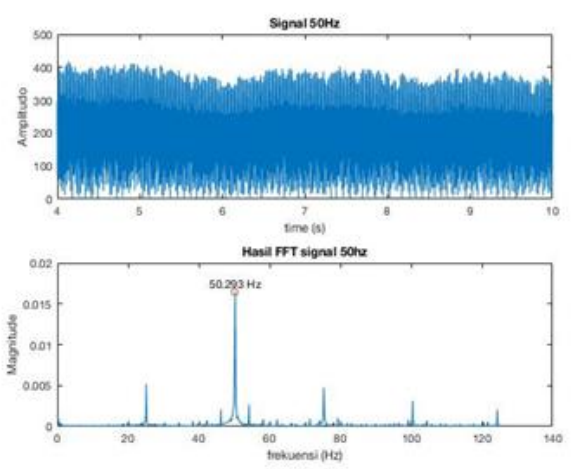

(b)

Gambar 5. Hasil Uji Respon Frekuensi (a) $10 \mathrm{~Hz}$ dan (b) $50 \mathrm{~Hz}$

Pada Gambar 4 di atas terlihat bahwa hasil FFT pada frekuensi $10 \mathrm{~Hz}$ puncak spektrum FFT yang dihasilkan adalah $10,1318 \mathrm{~Hz}$, pada spektrum $50 \mathrm{~Hz}$ puncak FFT yang dihasilkan adalah 50,2930 Hz. Simpangan frekuensi uji pada $10 \mathrm{~Hz}$ adalah $0,1318 \mathrm{~Hz}$, sedangkan simpangan pada frekuensi $50 \mathrm{~Hz}$ adalah 0,2930 Hz. Data hasil spektrum pada setiap frekuensi uji yang diberikan disajikan pada Tabel 1.

Tabel 1. Hasil spektrum FFT pada setiap frekuensi uji yang diberikan

\begin{tabular}{ccc}
\hline Frekuensi Uji (Hz) & $\begin{array}{c}\text { Puncak Spektrum } \\
\text { FFT } \\
\mathbf{( H z )}\end{array}$ & $\begin{array}{c}\text { Simpangan } \\
\mathbf{( H z )}\end{array}$ \\
\hline 10 & 10,1318 & 0,1318 \\
20 & 19,5318 & 0,4682 \\
30 & 29,4189 & 0,5811 \\
40 & 38,8184 & 1,1816 \\
50 & 50,2930 & 0,2930 \\
\hline
\end{tabular}

Dari Tabel di atas terlihat bahwa pada frekuensi uji $20 \mathrm{~Hz}$ puncak spektrum FFT yang diperoleh adalah $19,5318 \mathrm{~Hz}$, pada frekuensi uji $30 \mathrm{~Hz}$ puncak spektrum FFT yang diperoleh adalah $29,4189 \mathrm{~Hz}$ dan pada frekuensi uji $40 \mathrm{~Hz}$ puncak spektrum FFT yang diperoleh adalah 38,8184 Hz. Simpangan frekuensi uji dengan hasil spektrum FFT terbesar terjadi pada frekuensi $40 \mathrm{~Hz}$ yaitu 1,1816 Hz. Rata-rata simpangan yang dihasilkan adalah $0,5311 \mathrm{~Hz}$. Simpangan tersebut relatif kecil dan masih masuk dalam nilai toleransi sehingga dapat dikatakan bahwa sistem RSAM yang dirancang bangun mempunyai respon getaran yang cukup baik. Hal tersebut terlihat dari kesesuaian frekueansi uji yang diberikan dengan frekuensi hasil 
spektrum FFT yang diperoleh. Hal tersebut sekaligus membuktikan bahwa akurasi sistem yang dirancang bangun dapat mendeteksi sinyal uji dengan sangat baik.

\section{PENUTUP}

Simpangan antara frekuensi uji dengan spektrum FFT yang dihasilkan sangagt kecil yaitu 0,018 Hz. Keluaran frekuensi yang dihasilkan memiliki kesesuaian dengan frekuensi uji yang diberikan hal. Hal tersebut membuktikan bahwa sistem RSAM yang dirancang bangun mampu mendeteksi sinyal getaran dari frekuensi uji yang diberikan dengan sangat baik.

\section{UCAPAN TERIMA KASIH}

KEMENRISTEK-DIKTI yang telah mendanai penelitian ini dengan nomor kontrak PDP043/SKPP/2018.

\section{DAFTAR PUSTAKA}

Jurnal:

Ratdomopurbo, A. dan Sampurno, A., 2000, Standarisasi Instrumentasi Pamantauan Gunungapi, Direktorat Vulkanologi : Balai Penyelidikan dan Pengembangan Teknologi KegunungapianNama belakang, Nama depan. Tahun. Judul makalah/buku. Judul Jurnal atau media penerbit.

Salamah, U., Rusdiarna IP, A., Rizki, A.N., 2019, Design of Real-Time Seismic Amplitude Measurement (RSAM) System Using Geophone as the Detection of Seismic Vibration, Jurnal Migasian - AKAMIGAS Balongan Vol.3 No.2;21-24, Desember 2019.

Santosa, T.B. dan Huda, M., 2009, Analisis Sinyal dalam Domain Frekuensi. http://www.google.com/articel/command_set.pdf

Santoso,A.B., Lesage,P., Dwiyono,S., Sumarti,S.,Subandriyo, S., et al.. Analysis of the seismic activity associated with the 2010 eruption of Merapi volcano,Java. 2013.Journal of Volcanology and Geothermal Research, Elsevier, 2013, 261, pp.153-170

Walter, T.R., Wang, R., Zimmer, M., Grosser, H., Lühr, B., Ratdomopurbo, A., 2007, Volcanic Activity Influenced by Tectonic Earthquakes: Static and Dynamic Stress Triggering at Mt. Merapi, Geophysical Research Letters, Vol.34, L05304, doi: 10.1029/2006GL028710

Buku:

Suharno, Santoso, A.B., Sapari, Jilal, M., 2010,Statistik dan Analisis Seismisitas Merapi 2006, Laporan dan Kajian Vulkanisme Erupsi Merapi 2006 